\title{
Protein Concentration of Excretory-Secretory and Somatic Antigen of Paramphistomum spp.
}

\author{
Siti Rani Ayuti ${ }^{1}$, Muhammad Hambal ${ }^{2 *}$, Ummu Balqis $^{3}$, Henni Vanda ${ }^{4}$ \\ ${ }^{1}$ Biochemistry Department, Faculty of Veterinary Medicine, Universitas Syiah Kuala 23111, Indonesia \\ ${ }^{2}$ Parasitology Department, Faculty of Veterinary Medicine, Universitas Syiah Kuala 23111, Indonesia \\ ${ }^{3}$ Pathology Department, Faculty of Veterinary Medicine, Universitas Syiah Kuala 23111, Indonesia \\ ${ }^{4}$ Pharmacology Department, Faculty of Veterinary Medicine, Universitas Syiah Kuala 23111, Indonesia \\ *Corresponding author. Email: hambal.m@unsyiah.ac.id
}

\begin{abstract}
This study was aimed at finding out protein profile of excretory-secretory and somatic antigen of Paramphistomum spp. As many as 60 Paramphistomum spp. taken from cattle in Banda Aceh Municipality Slaughterhouse were placed into $80 \mathrm{ml}$ Roswell Park Memorial Institute (RPMI) 1640 and incubated for 12, 24, 48, and 72 hours. Excretorysecretory as well as somatic antigen was isolated and the concentration of protein was determined using Bradford method, and calibration curve was conducted using Bovine Serum Albumin as standard. To find out the molecular weight of protein, SDS-PAGE method was employed. The linear regression of calibration curve was $y=0.451 \mathrm{x}+$ 0.651. The highest concentrations of excretory-secretory antigen protein obtained was $235 \mathrm{ppm}$, and the somatic protein was $261 \mathrm{ppm}$. Weight of protein molecules was ranging from 29-130 kDa.
\end{abstract}

Keywords: excretory-secretory antigen, Paramphistomum spp., SDS-PAGE, protein profile, antigen isolation.

\section{INTRODUCTION}

The trematode parasite of Paramphistomun spp. are causative agent for paramphistomiasis in several hosts; cattle, goat, bufalloes and sheeps [1]. Paramphistomum spp. excysts in intestine and then juvenile flukes migrate to reticulum until reach adult stage [2-3]. This fluke will migrate when the temperature is around $25-30{ }^{\circ} \mathrm{C}$ with humidity around $85 \%$ [5]. Adult Paramphistomum spp. has 5-13 mm length and 2-5 mm width (5), while the egg has 113-175 $\mu \mathrm{m}$ length and 73-100 width with light yellowish and transparent appearance [3,6]. Living in rumen and abomasum of ruminants, this trematode causes retarded growth and significant economic lost. There was a report [7], stated a loss of US 2, 5 billion annually only in Indonesia. To cope with the pathogenicity and potential loss Paramphistomun spp. infection, appropriate control measures must be taken. Accurate diagnosis is substantial in determining the measures to be taken to eradicate this parasitic disease. On top of this, the search of specific antigen released by Paramphistomum spp. is also an alternative solution to overcome the disease. The development of immunology technique and molecular biology are standard tools in antigen and protein diagnosis [8-9], where the antigen is used as the target of antibody [2, 3, 10]. Excretorysecretory (ES) antigen can be found as protein resulting from metabolic processes when fluke is established in the host body $[8,9,11)$. Besides ES antigen, fluke also contain somatic antigen and superficial antigen which also can be recognized by the host $[4,12]$. However, ES antigen has a better capacity in triggering immune response and it is assumed that it has more protective effect in the immune system [2,9].

Excretory-secretory is an antigen produced by metabolism in helminths, which can stimulate host immune response [13]. Besides ES antigen, there are also somatic antigen and superficial antigen which could be recognized by the host to stimulate immune response. However, ES antigen are more potential compared to other antigen in provoking immune system and therefore are more beneficial as immunodiagnostic tool [14]. In this study, we would like to elaborate the identification and characterization of ES antigen, and further determine the concentration of ES antigen protein from Paramphistomum spp. Protein profile was also presented and analyzed using Bradford assay and Sodium Dodecyl Sulphate Poly-Acrylamide Gel Electrophoresis (SDS-PAGE). 


\section{MATERIALS AND METHODS}

This experiment was conducted to isolate and identify ES antigen protein from Paramphistomum spp. using Bradford assay. Protein concentration was determined based on calibration curve using Bovine Serum Albumin (BSA). Molecular weight of protein was visualized with SDS-PAGE.

\subsection{Isolation of ES Antigen and Somatic Protein of Paramphistomum spp.}

Paramphistomum spp. flukes were obtained from rumen and abomasum of cattle from slaughterhouse in Banda Aceh. As many as 60 flukes were rinsed six times with phosphate buffer saline (PBS), $\mathrm{pH} 7.3$, and then incubated in Roswell Park Memorial Institute (RPMI) 1640 media at $37{ }^{\circ} \mathrm{C}$ [15]. The protein isolated was differentiate between supernatant which contain ES antigen, and pellet for somatic antigen. The incubation time was 12 hours, 24 hours, 48 hours, and 72 hours.

\subsection{Bradford Assay}

This assay is widely used to measure protein concentration in a sample using BSA as a substrate. Bradford reagent was prepared by mixing $0.01 \mathrm{~g}$ Coomassie brilliant blue (CBB) G-250 with $5 \mathrm{ml}$ ethanol $95 \%(\mathrm{v} / \mathrm{v})$ and $10 \mathrm{ml}$ phosphoric acid $85 \%(\mathrm{v} / \mathrm{v})$. The mixture was homogenized, filtered, and stored in dark bottle at low temperature. Standard protein solution was prepared by dissolve $0.01 \mathrm{gr}$ BSA in $10 \mathrm{ml}$ sterile water to have a stock solution with $1000 \mathrm{ppm}$. This solution was diluted by adding $0.5 \mathrm{ml}$ stock solution with $4.5 \mathrm{ml}$ sterile water to obtain $100 \mathrm{ppm}$ solution. The solution was set for serial dilution at $0,10,20,30$, 40, 50, 60, 70, 80, 90, and $100 \mathrm{ppm}$. Protein standard was prepared by mixing $0.1 \mathrm{ml}$ of serial dilution with 5 $\mathrm{ml}$ of Bradford reagent, vortexed, and measured at 595 $\mathrm{nm}$ [16]. The protein concentration was calculated using linear regression from the standard protein marker.

\subsection{Sodium Dodecyl Sulphate Poly-Acrylamide Gel Electrophoresis (SDS-PAGE) Assay}

This assay was carried out to separate the protein based on molecular mass, ranged between 1-100 kDa, and visualized using electrophoresis. This method using coomassie brilliant blue for staining. The technique uses $3 \%$ (wt/vol) polyacrylamide gel and strengthened with $0.5 \%$ (wt/vol) agarose. The band present on the gel showed the molecular mass of the protein.

\section{RESULTS AND DISCUSSION}

In this study, ES antigen of Paramphistomum spp. was evaluated. The results of BSA standard absorption showed that the regression equation was $\mathrm{Y}=0.451 \mathrm{x}+$
0.651 , as presented in Figure 1. This standard curve is important to calculate the protein concentration of the sample, and the result showed that the absorbance in the sample ranged from $0.696-0.966$. The absorbance value of BSA standard curve is listed in Table 1.

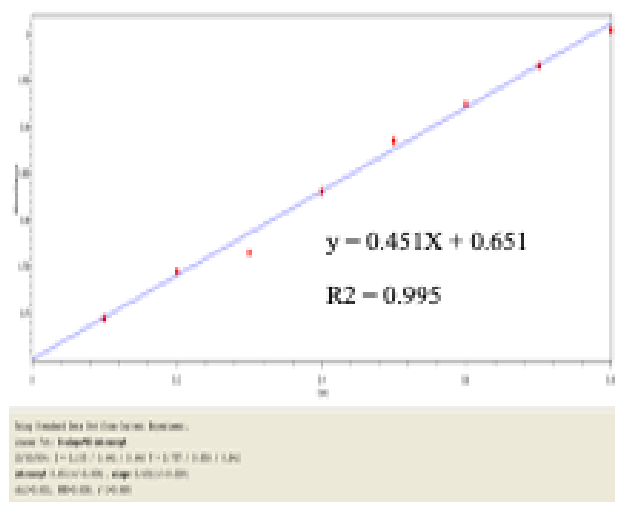

Figure 1 BSA solution standard curve

Table 1. Absorbance value of BSA standard curve

\begin{tabular}{|l|l|}
\hline BSA concentration $(\mathrm{mg} / \mathrm{mL})$ & Absorbance \\
\hline 0.1 & 0.696 \\
\hline 0.2 & 0.746 \\
\hline 0.4 & 0.831 \\
\hline 0.5 & 0.886 \\
\hline 0.6 & 0.924 \\
\hline 0.7 & 0.966 \\
\hline
\end{tabular}

Based on Bradford method, the protein concentration from pellet and supernatant was calculated, and it was ranged between 66-261 ppm (Table 2).

Table 2. Protein concentration of excretory-secretory and somatic antigen

\begin{tabular}{|l|l|l|}
\hline Treatment & Absorbance & $\begin{array}{l}\text { Protein } \\
\text { (ppm) }\end{array}$ \\
\hline Supernatant 12 hours & 0.715 & 142 \\
\hline Pellet 12 hours & 0.681 & 66 \\
\hline Supernatant 24 hours & 0.723 & 159 \\
\hline Pellet 24 hours & 0.712 & 135 \\
\hline Supernatant 48 hours & 0.757 & 235 \\
\hline Pellet 48 hours & 0.769 & 261 \\
\hline Supernatant 72 hours & 0.739 & 195 \\
\hline Pellet 72 hours & 0.748 & 215 \\
\hline
\end{tabular}


After 12 hours incubation, protein concentration in supernatant was higher (142 ppm) compared to pellet (66 ppm). After 24 hours, protein concentration in supernatant reached $159 \mathrm{ppm}$, while in pellet was 135 ppm. The highest concentration was obtained within 48 hours incubation, it was $235 \mathrm{ppm}$ in supernatant, and $261 \mathrm{ppm}$ in pellet. After 72 hours, the concentration was decreased both in pellet and supernatant. The high level of protein concentration in supernatant indicated the high level of ES antigen, while protein concentration in pellet indicated somatic antigen. Antigen which has major histocompatibility complex was owned by ES antigen with more specific protein structure. It is in accordance with study by Penn et al. [17] who conducted experiment with three trematode species. MHC is a group of genes which code for proteins found on the surface of cells that help the immune systems recognize foreign substances [18].

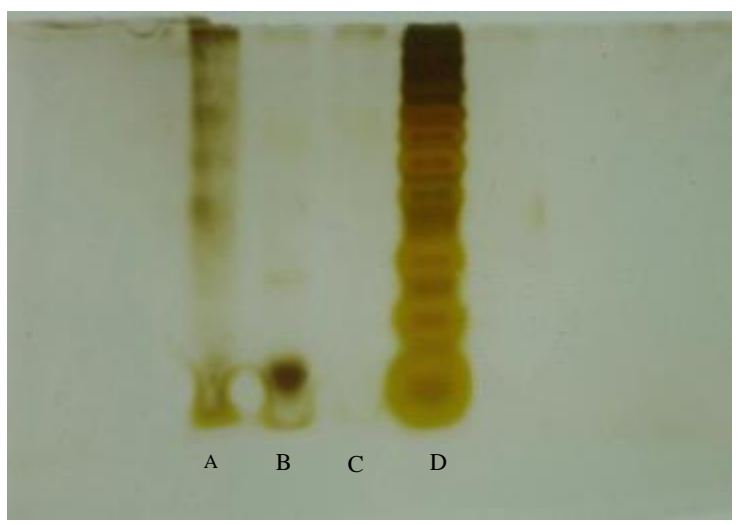

Figure 2 Visualization of protein bands in SDS-PAGE gel electrophoresis. A. 48 hours. B. 72 hours. C. 24 hours. D. Marker.

From SDS-PAGE result, it showed that the band of protein from ES antigen at 48-hour incubation was clearly seen, with molecular weight was ranged between 29-130 kDa. The band of protein at 24- and 72-hour incubation was degraded. The visualization of protein was presented in Figure 2. This figure points out that ES antigen of Paramphistomum spp. was present in the supernatant, and the media used in this experiment exhibited effectiveness for ES antigen isolation.

\section{CONCLUSION}

From the results it can be concluded that RPMI 1640 is a good choice for isolation of ES antigen from Paramphistomum spp. The optimum time for harvesting protein of ES antigen was 48 hours, and the concentration decreased over time. Molecular weight of ES antigen obtained was 29-130 kDa.

\section{AUTHORS' CONTRIBUTIONS}

The research was designed by $\mathrm{MH}$ and UB. The field work was conducted by $\mathrm{HV}$ and SRA. The manuscript was written by $\mathrm{MH}, \mathrm{HV}$, and SRA.

\section{ACKNOWLEDGMENT}

Author is thankful to the Research Institute of Universitas Syiah Kuala for funding this research. Author also wish to thank all the technical staff in the Laboratory of Parasitology, Pharmacology, and Laboratory of Research, Faculty of Veterinary Medicine, USK, for their assistance.

\section{REFERENCES}

[1] K.M. Huson, N.A. Oliver, M.W. Robinson, Paramphistomosis of ruminants: an emerging parasitic disease in Europe, Trends Parasitol. 33 (11) (2017) 836-844. DOI: 10.1016/j.pt.2017.07.002.

[2] P. Anuracpreeda, A. Watthanadirek, R. Chawengkirttikul, P. Sobhon, Production and characterization of a monoclonal antibody specific to 16ákDa antigen of Paramphistomum gracile, Parasitol. Res. 116 (1) (2017) 167-175. DOI: 10.1007/s00436-016-5273-1.

[3] P. Anuracpreeda, R. Chawengkirttikul, P. Sobhon, Antigenic profile, isolation and characterization of wholebody extract of Paramphistomum gracile, Parasite Immunol. 38 (7) (2016) 431-438. DOI:10.1111/pim.12330.

[4] K.M. Huson, N.A. Oliver, M.W. Robinson, Paramphistomosis of ruminants: an emerging parasitic disease in Europe, Trends Parasitol. 33(11) (2017) 836-844. DOI: 10.1016/j.pt.2017.07.002

[5] N.M. El-Bahy, E.K. Bazh, A. Elkhtam, New approach to molecular characterization of Paramphistomum cervi and Carmyerius gregarius and comparative analyses with selected trematodes, Parasitol. Res. 116(5) (2017) 1417-1422. DOI: 10.1007/s00436-016-5344-3.

[6] Q. Ali, I. Rashid, M.Z. Shabbir, H. Akbar, K. Shahzad, K. Ashraf, N. Sargison, U. Chaudhry, First genetic evidence for the presence of the rumen fluke Paramphistomum epiclitum in Pakistan, Parasitol. Int. 67 (5) (2018) 533-537. DOI: 10.1016/j.parint.2018.05.005

[7] M. Hambal, R. Ayuni, H. Vanda, Amiruddin, Farida, Occurence of Fasciola gigantica and Paramphistomum spp. infection in Aceh cattle, E3S Web of Conferences. (2020) 151-01025. DOI: https://doi.org/10.1051/e3sconf/202015101025 
[8] B. Meshgi, A. Eslami, F. Hemmatzadeh. Determination of somatic and excretory-secretory antigen of Fasciola hepatica and Fasciola gigantica using SDS-PAGE, Iranian J. Vet. Res. 9(1) (2008) 77-80. DOI: 10.22099/IJVR.2008.526.

[9] P. Anuracpreeda, J. Poljaroen, C. Chotwiwatthanakun, Y. Tinikul, P. Sobhon, Antigenic components, isolation and partial characterization of excretion-secretion fraction of Paramphistomum cervi, Exp. Parasitol. 133(3) (2013) 327-333. DOI: 10.1016/j.exppara.2012.12.00.

[10] V. Nagar, R. Shashidhar, J.R. Bandekar, Characterization of Aeromonas strains isolated from Indian foods using rpoD gene sequencing and whole cell protein analysis, World J. Microbiol. Biotechnol. 29(4) (2013) 745-752. DOI: 10.1007/s11274-012-1212-1

[11] M.A. Gomez-Morales, A. Ludovisi, M. Amati, E. Pozio. Validation of an excretory/secretory antigen based-ELISA for the diagnosis of Opisthorchis felineus infection in humans from low trematode endemic areas. PLoS One 8(5) (2013) p.e62267. DOI: $10.1371 /$ journal.pone.0062267

[12] A.K. Jaiswal, D. Shanker, V. Sudan, A. Singh, Diagnostic potential of low molecular weight excretory secretory proteins of Paramphistomum epiclitum for caprine amphistomosis, Vet. Parasitol. $257 \quad$ (2018) 5-9. DOI: 10.1016/j.vetpar.2018.05.009

[13] S.B.S. Mumpuni, Subekti, Kusnoto, Identifikasi fraksi protein spesifik excretorysecretory Fasciola spp. stadium dewasa dan juvenil. Majalah Kedokteran Hewan 22(1) (2006) 36-41.

[14] N.A. Kaushal, R. Hussain, E.A. Ottesen, Excretorysecretory and somatic antigens in the diagnosis of human filariasis, Clin. Exp. Immunol. 56(3) (1984) 567-576.

[15] F.N. Karanu, F.R. Rurangirwa, T.C. McGuire, D.P. Jasmer, Haemonchus contortus: identification of proteases with diverse characteristics in adult worm excretory-secretory products, Exp. Parasitol. 77(3) (1993) 362-371. DOI: https://doi.org/10.1006/expr.1993.1093.

[16] S.M. Gotham, P.J. Fryer, W.R. Paterson, The measurement of insoluble proteins using a modified Bradford assay, Anal. Biochem. 173(2) (1988) 353$358 . \quad$ DOI: $\quad$ https://doi.org/10.1016/00032697(88)90199-6.

[17] D.J. Penn. Major histocompatibility complex (MHC). e LS. 2001. DOI: https://doi.org/10.1038/npg.els.0000919.

[18] R. El Ridi, M. Salah, A. Wagih, H. William, H. Tallima, M.H. El Shafie, T.A. Khalek, A. El Amir, F.A. Ammou, H. Motawi, Fasciola gigantica excretory-secretory products for immunodiagnosis and prevention of sheep fasciolosis, Vet. Parasitol. 149(3-4) (2007) 219-228. DOI: https://doi.org/10.1016/j.vetpar.2007.08.024. 